\title{
Extracellular Matrix Molecules as Targets for Melanoma Therapy
}

\author{
Gerardo Botti*, Margherita Cerrone, Annamaria Anniciello, Rossella De Cecio, Paolo Ascierto, and Monica Cantile
}

National Cancer Institute-Fondazione Pascale, Naples, Italy

\begin{abstract}
Malignant melanoma, between human diseases, represents a best model to study tumor progression process. In fact, during its evolution, a series of events takes place involving several molecular mechanisms associated to both melanocytes transformation and to the surrounding microenvironment, with a prevalent involvement of Extracellular Matrix (ECM).

A large series of mechanisms correlated to the activity of these molecules have been studied to establish specific interfering system for target therapies in several human cancers. We suggest that the combination of specific ECM target therapies and immune-therapy, making more efficient the therapeutic approaches for malignant melanoma disease.
\end{abstract}

\section{Editorial}

The incidence of melanoma is gradually growing around the world, with particular increase among young individuals. The out-ofcontrol cell growth and the loss of cellular homeostasis play a key role in the genesis and progression of the tumor. At junction level these mechanisms control the proliferation, differentiation and apoptosis of melanocytes. In particular, interactions between transformed cells and transformed cell with extracellular matrix are crucial for melanoma progression. Molecules of the extracellular matrix in tumor microenvironment are responsible for tumor progression. Therefore, in order to establish specific target therapies, it is extremely important to set up molecular models which inhibit their activity.

Several studies have proved, for various tumor typologies, the possibility either to inhibit or interfere with the function of these molecules, both in vitro and in vivo. The inhibition can take place-at gene transcription level, using specific siRNA, as well as at protein level using specific antibodies against ECM proteins [1-7].

Silencing, employing specific siRNA, causes a reduction in cell proliferation, colony formation and invasiveness of tumor cells in vitro as demonstrated by Dong et al. [8] and Shen et al. [9] on metallo proteinases investigations. Besides in vitro studies carried out on cell models of melanoma have shown that the down-regulation by siRNA technique of MMP13 strongly enhanced pigmentation of melanocytes as well as a decreasing in cell proliferation [10].

MMP-2 silencing, through adenovirus-mediated and siRNA techniques in spinal metastatic melanoma model, significantly inhibits tumor growth and results in a complete retention of neurological function in animals [11].

Several molecules have been considered capable of inhibiting MMPs catalytic activity, especially pseudopeptides and non-peptidic molecules, which selectively bind themselves to zinc-bing site of these proteins. Batimostat, barimostat, AG3344 and bay-219566 are the most used molecules at present [12].

Many integrin-inhibitors have also been set up. They have a strong capacity of inhibiting the progression of neoplastic cells as shown by studies on animal models. In particular, Cyclic RGD peptides have been synthetized, which selectively inhibit alpha $\mathrm{v}$ integrins $[13,14]$. Synthetic peptides against alpha5beta1 and alphavbeta3 integrins are now days employed in pre-clinical studies [15-17]. "Disintegrins" represent another category of integrin inhibitors. They are small nonenzymatic proteins with the capacity of interacting with many cell types, including melanoma cells. Salmosin, Jararhagin, Eristostatin,
Contortrostatin and Obtustatin are the most studied and used "disintegrins" [18-22].

Anti-integrin antibodies have also been obtained (targeting alpha vs. integrins in particular): in mice model, Vitaxin and CNT095 strongly inhibit the growth of melanoma tumors [23].

The employment of RNA interference (siRNA), blocking Osteopontin (OPN) expression in melanoma cells, reduces cells number and invasiveness [24], whereas in other tumors, the employment of siRNA against OPN transcript causes a consistent suppression of tumorigenicity in vitro [25]. Beside, blocking of OPN expression can down-regulate other ECM molecules, specifically some metallo proteinases [26].

In recent years, several molecules have been identified as inhibitors of OPN, in particular Agelastatin A, an alkaloid with high anti-tumor efficacy [27]. Humanized monoclonal antibodies blocking OPN have been lately targeted: ASK 8007 , is very efficacious in patients with rheumatoid arthritis [28] and anti-human OPN antibody 1A12 is used in breast cancer treatment [29].

Regarding SPARC (Osteonectin) silencing, it has been shown that anti-sense expression vector in melanoma cells is capable of reducing the invasive and adhesive capacity of tumor cells [30]. Moreover, siRNA blocking SPARC expression in cell and animals models of melanoma, inhibits cell growth with G (1) arrest induction [31]. In uveal melanoma too, OPN silencing is capable of reducing tumor cells proliferation [32].

Small peptides have been recently synthesized. Their molecular structure is very simple, capable of binding different SPARC protein domains, blocking angiogenesis and inhibiting tumor growth as shown in animal models $[33,34]$.

*Corresponding author: Gerardo Botti, Department of Pathology, National Cancer Institute-Fondazione Pascale, Naples, Italy, Tel +39 081 5903766; Fax: +39 081 5903718; E-mail: gbotti1@alice.it

Received November 21, 2012; Accepted November 23, 2012; Published November 26, 2012

Citation: Botti G, Cerrone M, Anniciello A, De Cecio R, Ascierto P, et al. (2012) Extracellular Matrix Molecules as Targets for Melanoma Therapy. Clin Exp Pharmacol 2:e118. doi:10.4172/2161-1459.1000e118

Copyright: (c) 2012 Botti G, et al. This is an open-access article distributed under the terms of the Creative Commons Attribution License, which permits unrestricted use, distribution, and reproduction in any medium, provided the original author and source are credited. 
The effects of both siRNA [35] and monoclonal antibodies against different domains of Tenascin C protein has also been investigated [36].

Finally, CCN3 protein expression is in reverse correlation to neoplastic progression of melanoma. Many experiments on both induction and silencing of $\mathrm{CCN} 3$ have been carried out and the results have shown a subsequent alteration of adhesion capacity to laminin and vitronectin [37].

It is then feasible to assume that the improvement and progression of therapeutic approaches for melanoma could be achieved by the integration of specific therapies against ECM molecules combined with immunotherapy.

\section{References}

1. Aharinejad S, Sioud M, Lucas T, Abraham D (2007) Target validation using RNA interference in solid tumors. Methods Mol Biol 361: 227-238.

2. Kong HJ, Mooney DJ (2007) Microenvironmental regulation of biomacromolecular therapies. Nat Rev Drug Discov 6: 455-463.

3. Weidle UH, Maisel D, Klostermann S, Weiss EH, Schmitt M (2011) Differentia splicing generates new transmembrane receptor and extracellular matrixrelated targets for antibody-based therapy of cancer. Cancer Genomics Proteomics 8: 211-226.

4. Ye X, Yang D (2009) Recent advances in biological strategies for targeted drug delivery. Cardiovasc Hematol Disord Drug Targets 9: 206-221.

5. Hsu AR, Veeravagu A, Cai W, Hou LC, Tse V, et al. (2007) Integrin alpha V beta 3 antagonists for anti-angiogenic cancer treatment. Recent Pat Anticancer Drug Discov 2: 143-158.

6. Reardon DA, Zalutsky MR, Bigner DD (2007) Antitenascin-C monoclonal antibody radioimmunotherapy for malignant glioma patients. Expert Rev Anticancer Ther 7: 675-687.

7. Sanz L, Alvarez-Vallina L (2005) Antibody-based antiangiogenic cancer therapy. Expert Opin Ther Targets 9: 1235-1245.

8. Dong W, Li H, Zhang Y, Yang H, Guo M, et al. (2011) Matrix metalloproteinase 2 promotes cell growth and invasion in colorectal cancer. Acta Biochim Biophys Sin (Shanghai) 43: 840-848.

9. Shen YG, Xu YJ, Shi ZL, Han HL, Sun DQ, et al. (2012) Effects of RNAimediated matrix metalloproteinase-2 gene silencing on the invasiveness and adhesion of esophageal carcinoma cells, KYSE150. Dig Dis Sci 57: 32-37.

10. Meierjohann S, Hufnagel A, Wende E, Kleinschmidt MA, Wolf K, et al. (2010) MMP13 mediates cell cycle progression in melanocytes and melanoma cells: in vitro studies of migration and proliferation. Mol Cancer 9: 201.

11. Tsung AJ, Kargiotis O, Chetty C, Lakka SS, Gujrati M, et al. (2008) Downregulation of matrix metalloproteinase-2 (MMP-2) utilizing adenovirusmediated transfer of small interfering RNA (siRNA) in a novel spinal metastatic melanoma model. Int J Oncol 32: 557-564.

12. Nelson AR, Fingleton B, Rothenberg ML, Matrisian LM (2000) Matrix metalloproteinases: biologic activity and clinical implications. J Clin Oncol 18 1135-1149.

13. Gurrath M, Müller G, Kessler H, Aumailley M, Timpl R (1992) Conformation/ activity studies of rationally designed potent anti-adhesive RGD peptides. Eur J Biochem 210: 911-921.

14. Dechantsreiter MA, Planker E, Mathä B, Lohof E, Hölzemann G, et al. (1999) $\mathrm{N}$-Methylated cyclic RGD peptides as highly active and selective alpha(V) beta(3) integrin antagonists. J Med Chem 42: 3033-3040.

15. Carron CP, Meyer DM, Pegg JA, Engleman VW, Nickols MA, et al. (1998) A peptidomimetic antagonist of the integrin alpha(v)beta3 inhibits Leydig cell tumor growth and the development of hypercalcemia of malignancy. Cancer Res 58: 1930-1935.

16. Reinmuth N, Liu W, Ahmad SA, Fan F, Stoeltzing O, et al. (2003) Alphavbeta3 integrin antagonist S247 decreases colon cancer metastasis and angiogenesis and improves survival in mice. Cancer Res 63: 2079-2087.

17. Stoeltzing O, Liu W, Reinmuth N, Fan F, Parry GC, et al. (2003) Inhibition of integrin alpha5beta1 function with a small peptide (ATN-161) plus continuous
5-FU infusion reduces colorectal liver metastases and improves survival in mice. Int J Cancer 104: 496-503.

18. Kim DS, Jeon OH, Lee HD, Yoo KH, Kim DS (2008) Integrin alphavbeta3mediated transcriptional regulation of TIMP-1 in a human ovarian cancer cell line. Biochem Biophys Res Commun 377: 479-483.

19. Corrêa MC Jr, Maria DA, Moura-da-Silva AM, Pizzocaro KF, Ruiz IR (2002) Inhibition of melanoma cells tumorigenicity by the snake venom toxin jararhagin Toxicon 40: 739-748

20. Wierzbicka-Patynowski I, Niewiarowski S, Marcinkiewicz C, Calvete JJ, Marcinkiewicz MM, et al. (1999) Structural requirements of echistatin for the recognition of alpha(v)beta(3) and alpha(5)beta(1) integrins. J Biol Chem 274 37809-37814.

21. Trikha M, De Clerck YA, Markland FS (1994) Contortrostatin, a snake venom disintegrin, inhibits beta 1 integrin-mediated human metastatic melanoma cel adhesion and blocks experimental metastasis. Cancer Res 54: 4993-4998.

22. Marcinkiewicz C, Weinreb PH, Calvete JJ, Kisiel DG, Mousa SA, et al. (2003) Obtustatin: a potent selective inhibitor of alpha1beta1 integrin in vitro and angiogenesis in vivo. Cancer Res 63: 2020-2023.

23. Trikha M, Zhou Z, Nemeth JA, Chen Q, Sharp C, et al. (2004) CNTO 95, a fully human monoclonal antibody that inhibits alphav integrins, has antitumor and antiangiogenic activity in vivo. Int J Cancer 110: 326-335.

24. Zhou Y, Dai DL, Martinka M, Su M, Zhang Y, et al. (2005) Osteopontin expression correlates with melanoma invasion. J Invest Dermatol 124: 1044 1052.

25. Zhang P, Ozdemir T, Chung CY, Robertson GP, Dong C (2011) Sequentia binding of $\alpha \mathrm{V} \beta 3$ and ICAM- 1 determines fibrin-mediated melanoma capture and stable adhesion to CD11b/CD18 on neutrophils. J Immunol 186: 242-254.

26. Liu H, Chen A, Guo F, Yuan L (2010) A short-hairpin RNA targeting osteopontin downregulates MMP-2 and MMP-9 expressions in prostate cancer PC-3 cells. Cancer Lett 295: 27-37.

27. Mason CK, McFarlane S, Johnston PG, Crowe P, Erwin PJ, et al. (2008) Agelastatin A: a novel inhibitor of osteopontin-mediated adhesion, invasion, and colony formation. Mol Cancer Ther 7: 548-558.

28. Boumans MJ, Houbiers JG, Verschueren $P$, Ishikura $H$, Westhovens $R$, et al (2012) safety, tolerability, pharmacokinetics, pharmacodynamics and efficacy of the monoclonal antibody ASK8007 blocking osteopontin in patients with rheumatoid arthritis: a randomised, placebo controlled, proof-of-concept study. Ann Rheum Dis 71: 180-185

29. Dai J, Li B, Shi J, Peng L, Zhang D, et al. (2010) A humanized anti-osteopontin antibody inhibits breast cancer growth and metastasis in vivo. Cancer Immuno Immunother. 59: 355-366.

30. Ledda MF, Adris S, Bravo Al, Kairiyama C, Bover L, et al. (1997) Suppression of SPARC expression by antisense RNA abrogates the tumorigenicity of human melanoma cells. Nat Med 3: 171-176.

31. Horie K, Tsuchihara M, Nakatsura T (2010) Silencing of secreted protein acidic and rich in cysteine inhibits the growth of human melanoma cells with $\mathrm{G}$ arrest induction. Cancer Sci 101: 913-919.

32. Maloney SC, Marshall JC, Antecka E, Orellana ME, Fernandes BF, et al. (2009) SPARC is expressed in human uveal melanoma and its abrogation reduces tumor cell proliferation. Anticancer Res 29: 3059-3064.

33. Chlenski A, Guerrero LJ, Peddinti R, Spitz JA, Leonhardt PT, et al. (2010) Antiangiogenic SPARC peptides inhibit progression of neuroblastoma tumors. Mo Cancer 9: 138.

34. Uehara H, Luo L, Simonis J, Singh N, Taylor EW, et al. (2010) Anti-SPARC oligopeptide inhibits laser-induced CNV in mice. Vision Res 50: 674-679.

35. Zukiel R, Nowak S, Wyszko E, Rolle K, Gawronska I, et al. (2006) Suppression of human brain tumor with interference RNA specific for tenascin-C. Cancer Biol Ther 5: 1002-1007.

36. Wang YC, Zheng LH, Ma BA, Zhou Y, Fan QY (2010) Generation and identification of monoclonal antibodies against FNIII domain $D$ of human tenascin-C. Hybridoma (Larchmt) 29: 13-16.

37. Vallacchi V, Daniotti M, Ratti F, Di Stasi D, Deho P, et al. (2008) CCN3/ nephroblastoma overexpressed matricellular protein regulates integrin expression, adhesion, and dissemination in melanoma. Cancer Res 68: 715723. 